\title{
Effects of activity on the rate of barpressing by rats*
}

\author{
MELVIN' P. ENNS广 and N. R. REMLEY \\ Texas Christian Lniversity. Fort Worth, Texas 76129
}

\begin{abstract}
Rats deprived of 10 and 20; of their body weights and allowed to run in activity wheels immediately preceding a test session in a small rodent test chamber pressed a bar less frequently than comparably deprived rats not allowed to run in the wheels. The results support the hypothesis that running is an attempt by food-deprived rats to regulate an imbalance in a homeostatic mechanism(s) resulting from the deprivation of food.
\end{abstract}

It has been well documented that. following food deprivation. rats will increase their activity in running wheels (Finger. 1951: Moskowitz. 1959: Treichler \& Hall. 1962) and that this activity will increase even when many controls for associative components are present (Duda \& Bolles, 1963: Finger. 1965). Recent attempts to explain this phenomenon have proposed that the increase in energy expenditure is an attempt by the Ss to regulate some imbalance in a homeostatic mechanism(s) resulting from the deprivation of food (Hamilton, 1969: Routtenberg. 1968: Stevenson \& Rixon, 1957).

If food-deprived rats are regulating an imbalance in a homeostatic mechanism(s) by running, then animals allowed access to activity wheels should consume less food than animals confined to laboratory cages. This hypothesis has been supported both with food-deprived rats given limited feeding intervals (Routtenberg, 1968: Routtenberg \& Kuznesof, 1967; Strutt \& Stewart, 1970) and with rats fed ad lib (Levitsky, 1970). In addition, if food-deprived rats are regulating an imbalance in a homeostatic mechanism(s) by running, then rats deprived of food and allowed access to a running wheel should subsequently work less for food than Ss deprived of food but not given access to an activity wheel. The present study was designed to test this hypothesis

\section{METHOD}

\section{Subjects}

Thirty-two naive Holtzman male albino rats were used as Ss. The mean weight of the Ss was $338 \mathrm{~g}$ at the beginning of deprivation.

\section{Apparatus}

The apparatus consisted of eight Wahmann activity wheels with attached living cages. The wheels were housed in a room equipped with overhead fluorescent lighting, and the lights were

*The research was supported in part by a Texas Christian University Research Foundation grant awarded to N. R. Remley (Grant No. BMPS 6892).

$\div$ Present address: Department of Psychology. St. Lawrence University, Canton, New York 13617. on at all times during the experiment.

Two weight-control cage systems (Behavioral Controls, Inc.) were used. Each weight-control system consisted of six individual weight-control cages, one pellet dispenser, one selectofeeder, and associated relay circuitry. The system allowed the $\mathrm{E}$ to maintain the experimental animals at any given level of deprivation, or on an ad lib feeding schedule, and to record the Ss' weights without disturbing them. Single-pellet delivery was contingent on the S's tripping a relay in the foodcup, and the S was required to remove his head from the foodcup in order to reactivate the relay.

Three Grason-Stadler small rodent test chambers (Skinner boxes), programmed for continuous reinforcement and variable-interval reinforcement schedules, were also used.

\section{Procedure}

The Ss were divided into four groups of eight. Two of the groups (nonactive BP Groups 10 and 20) were deprived of food until they lost either $10 \%$ or $20 \%$ of their ad lib body weights, respectively. Following the deprivation period, these $S$ s were individually placed in one of the three Skinner boxes and trained to barpress for food. Following the barpress training, the Ss were given a 30-min test session in the Skinner box, using a VI 2-min schedule of reinforcement.

The two remaining groups were given 10 days adaptation to the activity wheels (active BP Groups 10 and 20), then deprived of $10 \%$ and $20 \%$ of their body weights, respectively. Following deprivation, the Ss were trained to barpress for food and then were replaced in the activity wheels. The time spent in the wheels depended on the. individual Ss. The Ss were removed from the wheels following two consecutive 5-min intervals, each containing less than 10 revolutions, or following a maximum period of $1 \mathrm{~h}$. At the completion of the postdeprivation test session in the activity wheels, the Ss were individually placed into the Skinner boxes and given a 30-min test session using a VI 2-min schedule.

\section{RESULTS}

The predetermined alpha level was 0.05 for all analyses. The observed alpha level for all results reported to be statistically significant is thus $p<.05$.

Prior to food deprivation, the difference in daily activity-wheel revolutions was not statistically significant across the active BP groups, but following food deprivation, the active Ss which lost $20 \%$ of their ad lib body weights ran significantly more revolutions than the active Ss which lost $10 \%$ of their body weights.

Both the Ss which lost $10 \%$ and the Ss which lost 20\% of their body weights significantly increased their rate of 


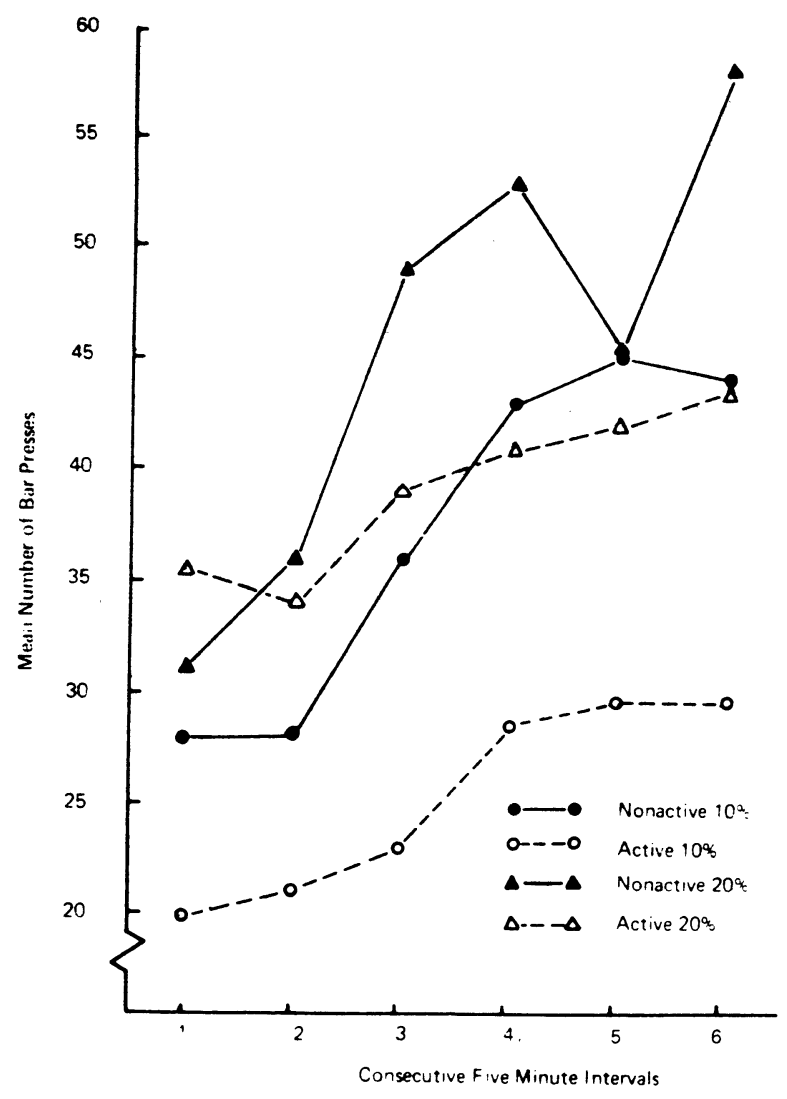

Fig. 1. Mean number of barpresses during consecutive 5-min intervals as a function of $10 \%$ and $20 \%$ body weight loss, respectively, and as a function of activity-wheel experience.

barpressing across the 30 -min test session, and the rate of barpressing by the Ss which lost $20 \%$ of their body weights was significantly higher than the barpressing rate exhibited by the Ss deprived of $10 \%$ of their body weights. Comparing the barpress rate of the active BP groups with the rate of the nonactive BP groups resulted in no overall statistically significant difference. But there was a statistically significant interaction across the 30-min test session as a function of activity-wheel experience. An examination of the simple effects associated with this interaction indicated that there were no statistically significant differences as a function of activity-wheel experience at either of the first two consecutive 5-min intervals, but, at each of the last four 5 -min segments, the barpress rate of the active BP groups was significantly lower than the barpress rate of the nonactive BP groups. The barpress data are illustrated in Fig. 1.

\section{DISCUSSION}

The barpress data lend support to the hypothesis that running regulates an imbalance in a homeostatic mechanism(s) and that this homeostatic regulation serves as a satiety signal. Ss given activity-wheel experience immediately preceding a $30-$ min test in a Skinner box pressed the bar significantly fewer times during each of the last four 5-min segments than comparably deprived Ss not given the activity-wheel experience. These data are consistent with other behavioral results which indicate that running affects food-motivated behavior. For example, Routtenberg and Kuznesof (1967), Routtenberg (1968), and Strutt and Stewart (1970) reported that, when compared with equally deprived rats living in laboratory cages, rats living in activity wheels exhibited a decreased food intake. Routtenberg and Kuznesof labeled this phenomenon "self-starvation." Levitsky (1970) reported the "self-starvation" phenomenon in rats fed ad lib. A possible reguiatory effect of running is also seen in a study by Collier and Levitsky (1968). These authors noted that food deprivation resulted in increased running, but when the amount of effort required to turn the rats' wheels was increased, running decreased.

Recently there have been attempts to specify possible mechanisms regulated by running. Stevenson and Rixon (1957) noted that during starvation the ability to conserve heat was reduced and suggested that running caused an increase in heat production and, thus, was one means by which body temperature could be maintained. Bolles and Duncan (1969) and Campbell and Lynch (1968), however, reported data which did not support the hypothesis that running was a behavioral attempt to regulate body temperature.

It has also been suggested that energy expenditure by deprived rats regulates the level of blood sugar (Campbell \& Lynch, 1968; Routtenberg, 1968), but data by Campbell and Fibiger (1970) and Strutt and Stewart (1970) do not support this hypothesis.

Serum-free fatty acid (FFA), the metabolically active form of fat, has been shown to increase with food deprivation and to decrease with food consumption (Van Itallie \& Hashim, 1960; Walker \& Remley, 1970). It has also been reported that the level of plasma FFA in humans decreases during exercise and then increases during a postexercise period (Carlson \& Pernow, 1961; Freidberg, Harlan, Trout, \& Estes, 1960; Rohdahl, Miller, \& Issekutz, 1964). Walker and Remley (1970) reported that barpressing on a variable-interval schedule of reinforcement by food-deprived rats reduced the level of serum FFA in the direction of the serum FFA level of rats fed ad lib. On the other hand, Gollnick (1967) reported that the plasma FFA level of rats maintained on an ad lib feeding schedule increased following $30 \mathrm{~min}$ of forced exercise. These data suggest a correlation between the level of circulating FFA and the degree of energy expenditures.

A recent criticism of the hypothesis that running regulates blood metabolites associated with food deprivation was made by Collier (1970). He presented evidence that the regulatory parameter appeared to be body size and composition rather than transient fluctuations in the level of some circulating metabolite. 
The data of the present study. consistent with the heharioral data reviewed. support the hypothesis that running regulates some imbalance in a homeostatic mechanism(s) associated with food-motivated behavior. There is a controversy. however, concerning the possible mechanism(s) regulated by running. It may well be that the long-term regulation of activity depends on body size and composition. just as Kennedy (1950) suggested that hody size and body composition were the long-term regulating parameters of food intake. Short-term individual bouts of activity. on the other hand, may be regulated by changes in the level of circulating metabolites. Investigations of changes in circulating metabolites and body size and composition for both short and extended bouts of activity are necessary before mechanisms regulated by running can be specified.

\section{REFERENCES}

Bolles. R. C.. \& Duncan, P. M. Daily course of activity and subcutaneous body temperature in hungry and thirsty rats. Physiology \& Behavior, 1969, 4, 87-89.

Campbell. B. A.. \& Fibiger. H. D. Effects of insulin on spontaneous activity during food deprivation. Journal of Comparative \& Physiological Psychology, 1970, 71, 341-346.

Campbell, B. A., \& Lynch, G. S. Influence of hunger and thirst on the relationship between spontaneous activity and body temperature. Journal of Comparative \& Physiological Psychology. 1968, 65, 492-498.

Carlson, L. A.. \& Pernow, B. Studies on blood lipids during exercise. II. The arterial plasma-free fatty acid concentration during and after exercise and its regulation. Journal of Laboratory \& Clinical Medicine, 1961, 58, 673-681.

Collier, G. Work: A weak reinforcer. Transactions of the New York Academy of Science, 1970, 32, 557-576.

Collier, G., \& Levitsky, D. A. Operant running as a function of deprivation and effort. Journal of Comparative \& Physiological Psychology, 1968, 66, 522-523.

Duda. J. J., \& Bolles, R. C. Effects of prior deprivation, current deprivation and weight loss on the activity of the hungry rat. Journal of Comparative \& Physiological Psychology, 1963, 56, 569-571.

Finger, F. W. The effect of food deprivation and subsequent satiation upon general activity in the rat. Journal of Comparative \& Physiological Psychology, 1951, 44, 557-564.

Finger, F. W. Effect of food deprivation on running wheel activity in naive rats. Psychological Reports, 1965, 16, 753-75.7.

Friedberg, S. J., Harlan, W. R., Jr., Trout, D. L., \& Estes, E. H.. $\mathrm{Jr}$. The effect of exercise on the concentration and turnover of plasma non-esterfied fatty acids. Journal of Clinical Investigation, 1960, 39, 215-220.

Gollnick, P. D. Exercise. adrenergic blockage, and free fatty acid mobilization. American Journal of Physiology, 1967, 213, 734-738.

Hamilton, C. L. Ingestion of nonnutritive bulk and wheel running in the rat. Journal of Comparative \& Physiological Psychology. 1969, 69, 481-484.

Kennedy. G. C. The hypothalamic control of food intake in rats. Proceedings of the Royal Society of London, 1950, 137. 535-549.

Levitsky, D. A. Feeding patterns of rats in response to fasts and changes in environmental conditions. Physiology \& Behavior, $1970,5,291-300$.

Moskowitz, M. J. Running-wheel activity in the white rat as a function of combined food and water deprivation. Journal of Comparative \& Physiological Psychology, 1959, 52, 621-625.

Rohdahl, K., Miller, H. I., \& Issekutz, B., Jr. Plasma free fatty acids in exercise. Journal of Applied Physiology, 1964, 19, 489-492.

Routtenberg, A. "Self-starvation" of rats living in activity wheels: Adaptation effects. Journal of Comparative \& Physiological Psychology, 1968, 66, 234-238.

Routtenberg, A., \& Kuznesof, A. W. Self-starvation of rats living in activity wheels on a restricted feeding schedule. Journal of Comparative \& Physiological Psychology, 1967, 64, 414-421.

Stevenson, J. A. F., \& Rixon, R. H. Environmental temperature and deprivation of food and water on the spontaneous activity of rats. Yale Journal of Biological Medicine, 1957, 29. 575-584.

Strutt, G. F., \& Stewart, C. N. The role of blood glucose in activity related self-starvation. Psychonomic Science, 1970 , $18,287-289$.

Treichler, F. R., \& Hall, J. F. The relationship between deprivation weight loss and several measures of activity. Journal of Comparative \& Physiological Psychology, 1962, 55 . 346-349.

Van Itallie. T. B.. \& Hashim, S. A. Biochemical concomitants of hunger and satiety in man. American Journal of Clinical Nutrition. 1960, 8. 587-594.

Walker. D. W., \& Remley, N. R. The relationship among percentage body weight loss, circulating free fatty acids, and consummatory behavior in rats. Physiology \& Behavior, 1970, 5. 301-309.

(Received for publication August 24, 1972; accepted September 7, 1972.) 